\title{
Actions after the Xynthia storm on the French Atlantic Coast
}

\author{
Marc Jacquet ${ }^{1}$, Jean-Marc Kahan ${ }^{1}$ and Jean-Philippe Lalande ${ }^{1, a}$ \\ ${ }^{1}$ Ministry of Environment, Energy and Sea, Paris, France
}

\begin{abstract}
After the dramatic events of 27 February 2010, during the passage of the storm Xynthia, State has established in February 2011 a national plan for rapid submersions, the National plan for rapid submersions (Plan Submersions Rapides - PSR) which aims by 2016 to increase the security of people in flood zones. The PSR has created a new dynamic and notably led many communities to carry flood prevention action programs (PAPI). 127 PAPIs and dykes projects are certified to date representing $€ 1.463$ billion. In departments of Charente-Maritime and Vendée, 28 PAPIs have been developed and cover the most severely affected territories by Xynthia storm. Besides the implementation of PAPI carried by local authorities, the State has driven 81 operational actions contributing to manage urban development, to improve the knowledge of hazards, the development of forecasting and monitoring systems, the information of populations and the reliability of the protection structures. A new regulation for "management of aquatic environments and flood prevention" was created and should be established at the initiative of local communities until the $1^{\text {St }}$ January 2018.
\end{abstract}

\section{The Xynthia windstorm}

Xynthia was a violent European windstorm which crossed Western Europe between 27 February and 1 March 2010. It crossed France on the night of 27-28 February 2010.

The sea levels recorded between the estuary of the Loire and the estuary of the Gironde were over 100-year recurrence intervals (a surge of over $1.50 \mathrm{~m}$ was recorded at La Rochelle). The simultaneous force of the wind and the high spring tides were the main cause of these high water levels (Figure 1).

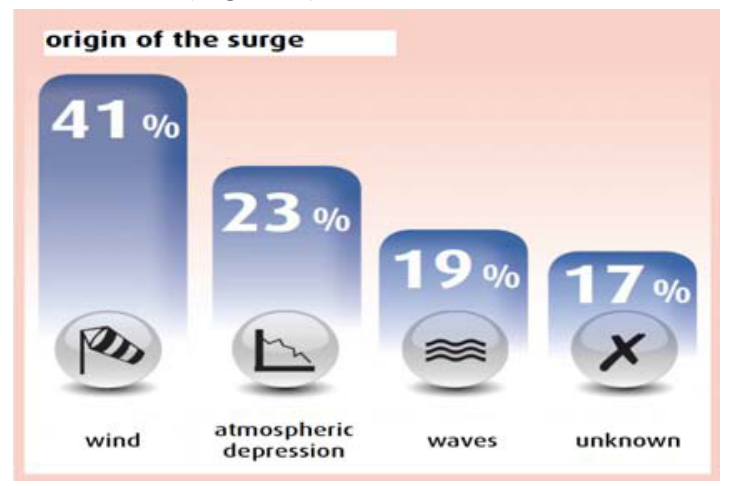

Figure 1: Percentage of phenomena involved during the Xynthia storm
Xynthia storm showed no exceptional wind speed (maximum wind speed on the coast: $160 \mathrm{~km} / \mathrm{h}$ at the tip of Ile de Ré). It reached a minimum pressure of $967 \mathrm{mb}$ on 27 February.

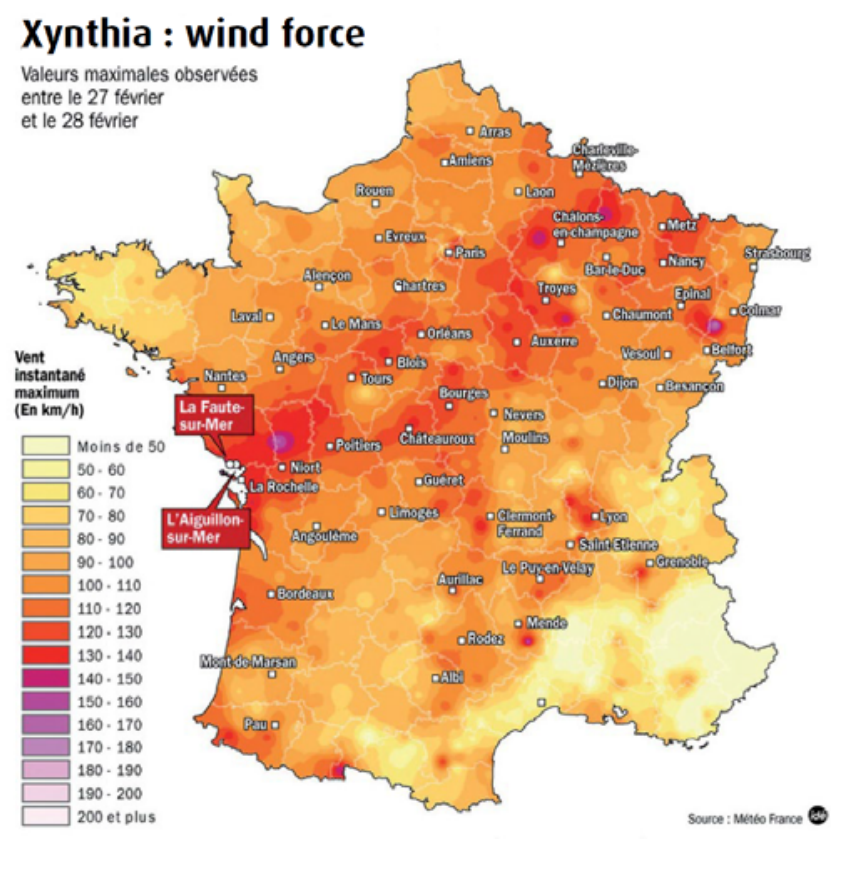

Figure 2: Distribution of maximum wind speed observed during the Xynthia storm (27-28 Feb. 2010)

\footnotetext{
$\overline{{ }^{a} \text { Corresponding author: jean-philippe.lalande@developpement-durable.gouv.fr }}$
} 


\subsection{Dramatic consequences}

Xynthia caused a number of coastal floods along the departments of the Vendée, Charente-Maritime, LoireAtlantique and Gironde (over 70,000 hectares) killing 47 people and causing damage estimated to 2.5 billion euros, including $200 \mathrm{~km}$ of damaged seawalls. 29 people were killed in La Faute-sur-Mer, in a depression at one meter below sea level, below the dykes on Lay coastal river.

Well anticipated, the storm resulted in relevant warnings thanks to the "strong wind" vigilance chain. However, the flooding phenomenon was underestimated in the absence of specific operational framework for marine submersion, which would have been necessary to disseminate appropriate safety information [1].

The mobilization of rescue services proved remarkable, to save more than 1500 people. The severity of the impact of the storm remains partly related to the underestimation of the level of risk in flooding prevention policy and the coastal urbanization. Add to this a low risk culture of citizens and a lack of maintenance of some protective structures.

\subsection{National solidarity in action}

Immediately after the storm, emergency work was carried out to ensure protection against the next tides. Two levels of intervention on the damaged structures have followed and concerned nearly 190 projects completed in 2010 (120 in Charente -Maritime and 70 in Vendée 70). In Charente -Maritime, after the work of first aid in March 2010, 88 reinforcement operations were carried out relating to all types of defense (masonry dams, earth, sand dunes) in the amount of works $€ 18 \mathrm{~m}$ of which $€ 9.4$ million funded by the State. In Vendée, 56 emergency repair works on dunes were launched in the department for an amount of $€ 13.9$ million of work which $€ 6.1$ million funded by the State (see figure 3 ).

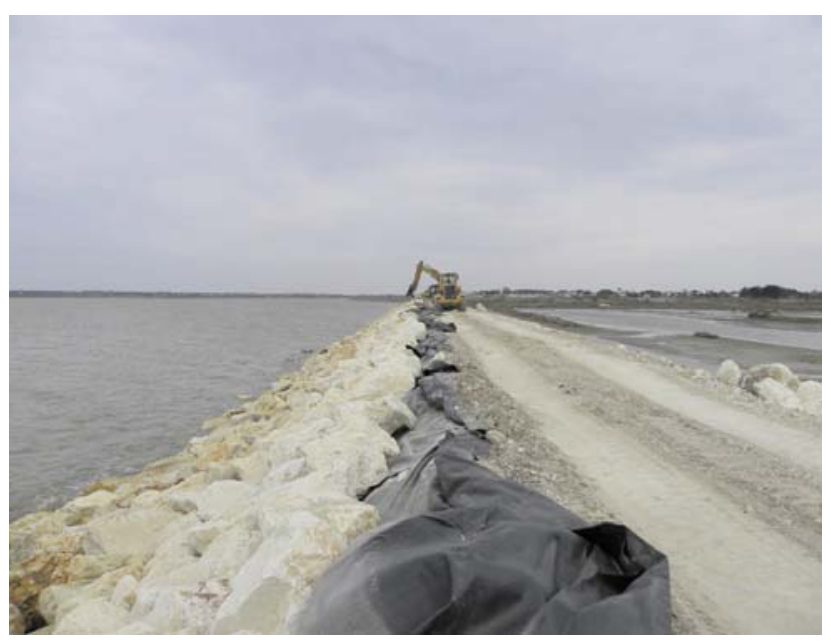

Figure 3: Emergency repair work on a protection dyke

In the areas most dangerously at risk from sea floods, amicable purchase boundaries were marked out to enable the people living there to resettle elsewhere, under satisfactory economic conditions. 1,162 properties were amicably purchased at the end of 2014 for a total sum of
$€ 315 \mathrm{~m}$ paid by the National Major Risks Prevention Fund (FPRNM). In time, this program will involve 1,167 properties. For properties not acquired amicably, expropriation proceedings were initiated in Vendée in the towns of La Faute -sur -Mer and l'Aiguillon -sur -Mer and continue to end exposure to risk serious.

Studies to reclassify the damaged areas were carried out in the Vendée, in the municipalities of La Faute sur Mer and L'Aiguillon sur Mer, and over a greater area in Charente-Maritime, which was the subject of a national seminar. The aim of these studies was to redefine the purpose of these sites, for activities compatible with the risk of coastal flooding. Local stakeholders, supported by the Government, are working to fulfill these projects.

\section{The national plan for rapid submersions (PSR)}

The plan for rapid submersions (PSR), a national and interministerial plan, was approved February 17, 2011, following floodings by storm Xynthia February 28, 2010, and the other catastrophe due to flash floods in the Draguignan area, Var, 15 June 2010 [2]. It covers the risk of flooding by coastal flooding, flash flooding or runoff and localized dike breaches.

This plan on rapid flooding is meant as an emergency device to increase the security of populations in endangered zones. It anticipated the implementation of the Floods Directive [3] which includes four phases: preliminary flood risk assessment in 2011, designation of territories with significant flood risk in 2012 together with their maps in 2013-2014, development of flood risk management plans 2015 and local strategies on the territories with significant flood risk for the end of 2016, the whole being covered by the national flood risk management strategy approved in the summer of 2014. Its measures and actions will be integrated in the various documents on flood risk management and risk prevention, with the general framework provided by the national strategy.

Its aim is to encourage territories to develop and implement prevention projects to ensure the safety of people towards these hazards through a pragmatic approach also integrating individual projects but on consistent areas.

The PSR is divided into four themes:

- controlling urban development and adaptation of existing buildings;

- improving knowledge of hazards and monitoring of forecasting, vigilance and alert systems;

- reliability of structures and protection systems;

- improving resilience.

It relies on 71 thematic and 9 structuring actions, several of them being performed, such as the establishment by Météo-France of the "Wave Submersion Vigilance" component within the meteorological vigilance, as well as the "warning service for heavy rainfall" (APIC) on the scale of municipalities, the repository of technical construction in flood zones, and the integration of evacuation routes in the municipal safeguard plans. 
The PSR is endowed by the State, for a 6 years period, with a grant allocation of $€ 500$ million mainly from major natural risk prevention fund, plus the financing of local authorities. It allows in particular to reinforce $1200 \mathrm{~km}$ of dikes. This funding is structured with those of flood prevention action programs (PAPI), which are global programs mobilizing all flood risk prevention tools at the scale of a risk territory, and for which the State is committed to funding at $€ 350$ million over the same period.

The labeling of PAPI and "PSR" projects will ensure the coherence of actions, in the purpose of prevention and securing, and taking into account the protected areas. Steps are underway with state agencies to reduce the time of preparation and realization of dike building projects (called "PSR") otherwise subject to administrative procedures. For this purpose, a simplification of PSR labeled projects included in a PAPI has been conducted since October 2013 on the territories affected by Xynthia. This represents a total of $530 \mathrm{~km}$ of dikes (made of 405 $\mathrm{km}$ from PSR projects listed in PAPI and $125 \mathrm{~km}$ from PSR projects out of PAPI).

\subsection{Examples of measures for controlling urban development and adaptation of existing housing}

Due to pressures of urbanization of economic, social or land origins, rivers, coastal zones and surrounding areas have often been built, covered, diverted, increasing the vulnerability of people, goods (economic and cultural) and the environment.

The control of urbanization in flood zones and adaptation of existing housing are important tools for risk prevention to be developed.

\subsubsection{Flood risk prevention plans}

The development of natural risk prevention plans (PPRN) is a priority to control urbanization, going up to the ban in areas at risk. At the end of 2015, more than 10,800 towns are covered by an approved PPRN. The annual rate of approval is of the order of 350 to 400 municipalities covered by a new or revised PPRN. 303 coastal municipalities in the metropolis have been specifically identified, for which natural coastal risk prevention plan should be established as a priority, within three years. At the end of 2015, 272 were prescribed or approved and 92 applied in advance (Figure 4). State services in consultation with communities pursues the development of priority coastal risk prevention plans [4] identified in 2011 by the ministerial circular of 2 August 2011 to ensure the control of urban development and to limit exposure to coastal risks (30 municipalities are involved in the Pays de Loire, Poitou-Charentes 81).

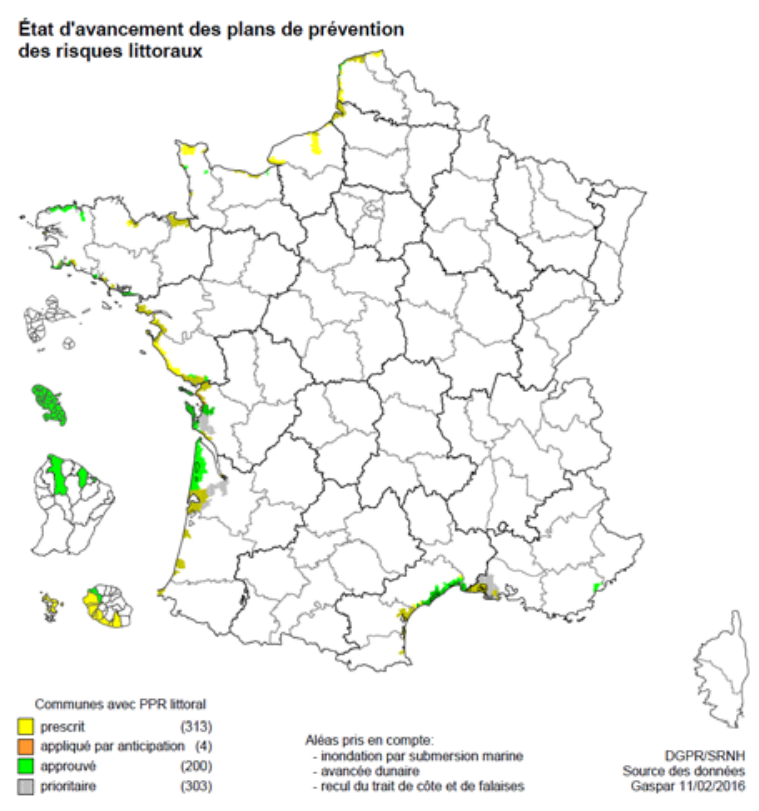

Figure 4: Location of coastal risk prevention plans (as Feb 2016)

\subsubsection{Guideline on flood prevention measures for existing housing}

A national repository of prevention work for existing housing was conducted in order to identify, standardize and formalize all preventive measures contained in the existing guidelines made in the domain of flood prevention and risk prevention plans (PPR). This guideline is designed as a repository for the building sector professionals (Figure 5). http://www.developpement-

durable.gouv.fr/Referentiel-de-travaux-de.html

This repository has been developed with a view of a tool for selection and assistance in implementing preventive measures and designed for practical use through the provision of work sheets and case studies.

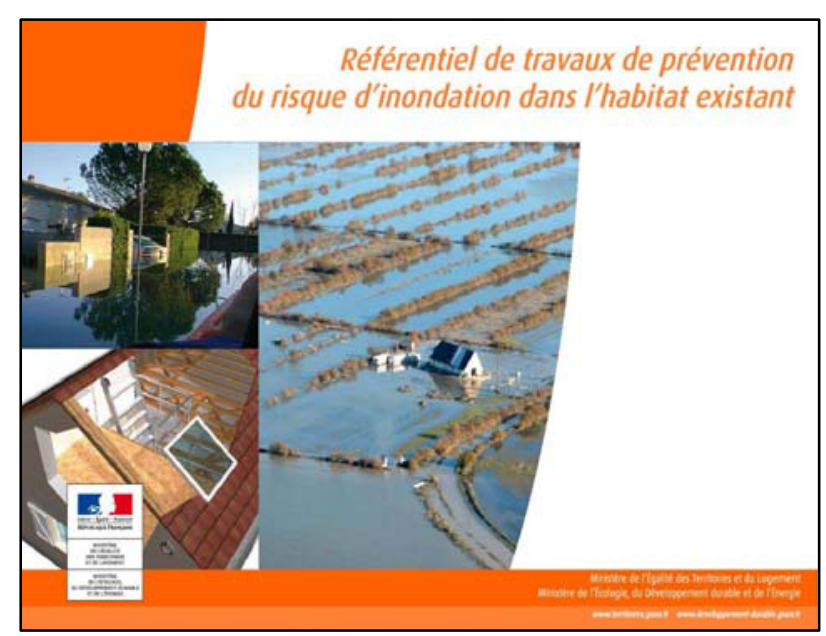

Figure 5: Cover page of the guideline on flood prevention measures for existing housing 


\subsubsection{Consideration of flooding risk in urban projects. The Grand Prix 2016: "How to improve construction in building land liable to flooding"}

Announced by Mrs Ségolène Royal, Minister of the environment, on July 10, 2014, the Grand Prix aims to promote innovation in the context of construction projects, either completed or in progress, in the purpose of strengthening the individual and collective resilience to flooding. It aims to investigate how best to build in constructible land liable to flooding only if the people who live there or work there are not endangered during the passage of the flood or during groundwater floods.

This Grand Prix is therefore awarded on constructible land where the hazard is neither strong nor serious to human life. It is particularly meant for existing neighborhoods undergoing urban renewal. Awards Grand Prize will be awarded March 22, 2016 during the National Conference of natural hazards in Marseille http://www.developpement-durable.gouv.fr/-Assises2016-.html

\subsection{Examples of measures for improving knowledge of hazards, for monitoring and forecasting systems, vigilance and alert}

Improving the knowledge of hazards and forecasting systems, as well as vigilance and alert, allowed to develop new products and to install new equipment in the country, which are more suitable for intense and fast phenomena.

\subsubsection{Implementation of the "waves - submersions" meteorological vigilance}

Meteo France has launched in October 2011 in partnership with the Naval Hydrographic and Oceanographic Service (SHOM), and in conjunction with the Ministries of Environment and Interior, a new component of the meteorological vigilance, called "waves - submersions", which aims to better anticipate the sea level rising that may affect the metropolitan coast.

\subsubsection{Extension of "flood" vigilance system}

This device enables the monitoring of the metropolitan rivers on more than $21700 \mathrm{~km}$ of watercourses today, especially with the recent progress on forecasting tools, to areas upstream or downstream sectors under marine influence. This information is updated twice daily. Real-time data is also available. Flood vigilance, identified by a registered trademark (Figure 6), is freely accessible for all interested audiences, particularly professional on http://www.vigicrues.gouv.fr/. This information is also necessary for authorities in charge of civil security (prefects and mayors) which, when the situation requires, trigger and mobilize emergency services. Vigilance can anticipate the crisis and thus manage the alert in good conditions.

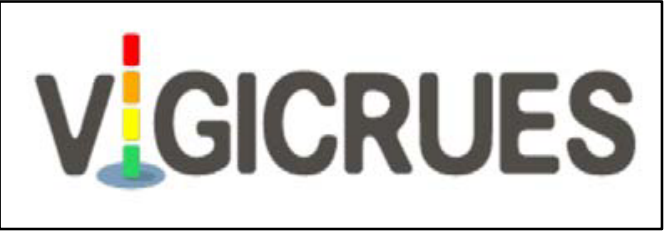

Figure 6: the VIGICRUES registered trademark created for the flood vigilance system

\subsubsection{The APIC system (warning about heavy rainfall for municipalities) and the future ACS service (flash flood warning)}

The APIC system developed by Météo-France, is based on the real-time observation of rainfall thanks to radar and rain gauges on the ground. It is operational since early December 2011, with a possibility of phone service (SMS), free for prefects and mayors, and for a number of people they designate. The mayors were invited by the prefects to integrate this system into their municipal safeguard plans (PCS). More than 6200 towns had already subscribed by the end of 2015 .

DGPR (via SCHAPI and SPC) is preparing a new warning service on the possibility of flash floods, in addition to the APIC service in order to shorten the chain of information to the people, especially on small watersheds which are not surveyed under the "flood" vigilance system. The first warning productions are planned for 2016 on the most vulnerable areas.

\subsubsection{The renewal of weather radar and rain gauges}

A multi-year agreement between Météo France and the Ministry of Environment is signed to renew and complete networks of weather radars and rain gauges, which are essential to improve the performance of forecasting and warning systems. End of 2015, two new radars have been renewed in St. Nizier and Arcis sur Aube.

\subsection{Examples of measures for improving the reliability of structures and protection systems}

The reliability of structures and protection systems has been questioned during storms and flash floods in 2010.

The main actions to ensure better protection of people and assets in the flood zone have focused on the search for a new framework of project ownership, on financial support from the State to communities to carry out repair work dykes and on strengthening security controls by the State.

2.3.1 The call for PAPI projects (flood prevention action program) and the work for strengthening the dykes.

This call for projects can finance a coherent set of actions on a territory and encourage the emergence of managers of protective structures in this territory. 
Beginning 2016, 127 flood prevention action programs and projects labeled "national plan for rapid submersion" were selected through a renovated procedure (Figure 7). Many coastal communities are engaged in the PAPI / PSR approach. Thus, among these projects, 36 are related to actions on the prevention of coastal flooding (PAPI 25 and 11 PSR out PAPI), representing $€ 355$ million investment and $264 \mathrm{~km}$ of protective structures.

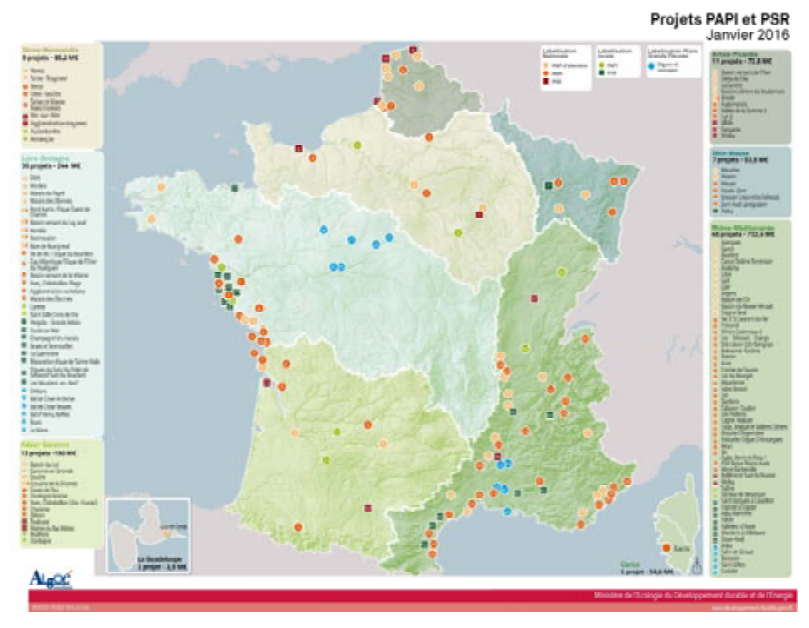

Figure 7: location of the 127 actions plans (PAPI and PSR programs) by Jan. 2016

\subsubsection{The creation of GEMAPI regulation}

The regulation for management of aquatic environments and flood prevention (called GEMAPI) was created by the law of 27 January 2014 modernizing the local public action and the new organization of metropolis [5].

It comes into force on 1 January 2018. It is entrusted to municipalities and their public establishments for intercity cooperation (EPCI) with their own taxation powers. This skill will ensure the sustainable management of protection works by competent contractors and the building and maintenance of these structures, and benefit from the tax for the management of aquatic environment and flood prevention, which is an optional dedicated and leveled out tax created by the same law.

\subsubsection{The organisation France Digues}

Created on 22 May 2013, the organisation France Digues leads and works with the network of public managers of flood barriers and works defending against rises in water level and marine submersion http://www.france-digues.fr/ . It brings together public managers and research bodies and acknowledged experts in this field.

\subsection{Examples of measures for improved resilience and risk culture}

Improving the resilience of territories and populations against rapid flooding is a necessary step so that people can live normally in exposed areas.
For this, it is possible to act on several components, for example, on the knowledge of phenomena and adaptation of territories, on preventive information and education, on preservation of the memory of past flooding.

\subsubsection{Information of populations: remembering the risk}

Flood marks are historical witnesses of past major floods, designed to keep alive the memory of the floods. 2,000 marks have been produced and provided to the Mayors, to remember the Xynthia windstorm (Figure 8).
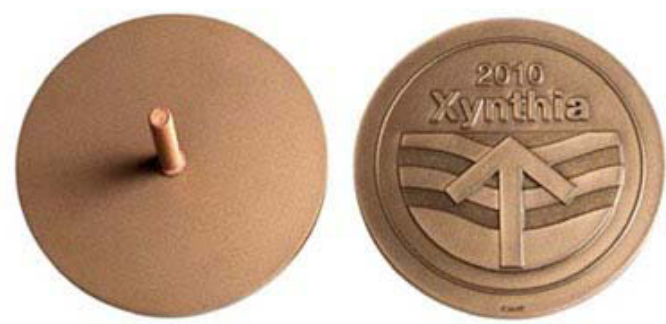

Figure 8: Flood marks placed after the Xynthia storm

\section{After Xynthia, the most affected areas were particularly mobilized to prevent further flooding}

\subsection{Implementation of comprehensive flood management programs along the coast of Charente-Maritime and Vendée}

In Charente-Maritime and Vendée, 28 flood prevention action programs (PAPI) and containment projects (called "PSR") have been developed and cover all the most affected by Xynthia territories, for a total investment of $€ 260$ million to which the State contributes $€ 96$ million. These projects include the strengthening of $224 \mathrm{~km}$ of dykes.

Since 2010, many dyke systems have been strengthened or created in Charente-Maritime and Vendée to protect, where possible, areas at risk of flooding. In Charente-Maritime, this is the Bas Bizet dyke (Charron), the Charron western dyke (phase 1 and 2), the Boutillon dyke (Ars en Re) (see Figure 9), the protection from Port des Barques (Phase 1), the breakwater of the north beach and the protection of the Boucholeurs district (Châtelaillon) and the Doreaux district (St. Clement of Whales, ongoing). 


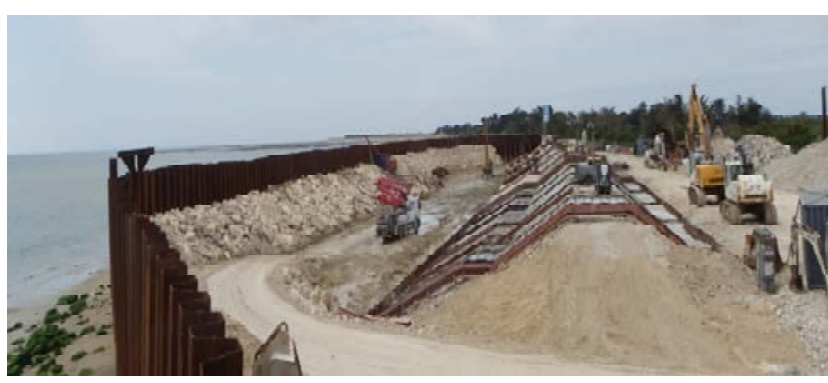

Figure 9: Reconstruction works on the Boutillon dyke (17), July 2015 (PAPI of Ile de Ré and PSR of Boutillon labeled on July 12, 2012)

In Vendée, this work mainly involved the rehabilitation of the belle Henriette dune ridge (La Tranche sur mer), the south dyke of Gois, the Bouchard dyke and the stone protections of Gueriniere (Noirmoutier), Barre Monts dykes and protections of Fromentine, Gorin quay (St Gilles Croix de Vie), the dykes of Grues and Grenouillet in Aiguillon-sur-Mer and the eastern dyke of the Faute-sur-Mer.

New enhancements are planned in 2016. In CharenteMaritime, it concerns the protections of Esnandes, Aytré, of Port-des-Barques, Loix, Boyardville and Saint Trojan. In Vende, these reinforcement work will concern the stone protections of the Gueriniere (Noirmoutier), dykes of Tendeau and polder of Rouches (La Barre-de-Monts), the stone protections Demoiselles, Becs and Gulls (StHilaire-de -Riez), the Gachères dam, the Belle Henriette dyke (La Tranche-sur-Mer), the Eastern dyke (La Fautesur-Mer) and the du Génie dyke (Aiguillon-sur-Mer).

\subsection{Expropriation conducted in the solidarity areas}

Areas of amicable acquisition, called "solidarity zones" were originally delimited in April 2010 to enable people living in particularly exposed areas to resettle in economically satisfactory conditions, outside the risk areas. This approach helped quickly to avoid a serious threat to human life for the people who accepted the State's proposal. 1162 properties have been amicably acquired in 2015 for a total of $€ 317.71$ million paid on Natural Risk Prevention Fund (FPRNM).

At the same time as protective solutions were sought and initiated where it was feasible, expertise helped determine assets being not yet amicably purchased and remaining exposed to serious threats to human lives.

For properties not acquired amicably, expropriations were initiated in Vendée in the towns of La Faute-sur-Mer and l'Aiguillon-sur-Mer and continue to end exposure to serious risk. $€ 10.7$ million were delegated to the prefects in 2013, $€ 1.2$ million in 2014 to undertake the expropriation measures involving 93 land units on L'Aiguillon-sur-Mer and 10 units on La Faute-sur- Mer.

In Charente-Maritime expropriation procedures have been launched in the towns of Charron ( 7 houses), Aytré (6 properties), Port des Barques (1 house), Fouras (4 houses), St Trojan-les- Bains (Ile d'Oleron), Loix (Ile de Ré) and the island of Aix. $€ 4.4$ million of FPRNM were delegated to the Prefect in 2014 and $€ 12.87$ million in
2015. Regarding the properties exposed in the municipality of St Mathes (Boyardville) prevention solutions have helped secure goods.

\begin{tabular}{|r|c|c|c|}
\hline & Vendée & $\begin{array}{r}\text { Charente } \\
\text {-Maritime }\end{array}$ & Total \\
\hline $\begin{array}{r}\text { number of } \\
\text { affected properties }\end{array}$ & 841 & 826 & 1667 \\
\hline $\begin{array}{r}\text { number of } \\
\text { properties for } \\
\text { residential use }\end{array}$ & 811 & 757 & 1568 \\
\hline $\begin{array}{r}\text { acquisition } \\
\text { proposals made by } \\
\text { the State }\end{array}$ & 804 & 535 & 1339 \\
\hline $\begin{array}{r}\text { proposals } \\
\text { accepted }\end{array}$ & 703 & 464 & 1167 \\
\hline $\begin{array}{r}\text { agreement rate on } \\
\text { proposals }\end{array}$ & $87,43 \%$ & $86,7 \%$ & $87,1 \%$ \\
\hline $\begin{array}{r}\text { number of } \\
\text { acquisitions }\end{array}$ & 701 & 461 & 1162 \\
\hline $\begin{array}{r}\text { TOTAL } \\
\text { Amount }\end{array}$ & 159,8 & 157,91 & 317,71 \\
\hline $\begin{array}{r}\text { (M) } \text { cost per } \\
\text { aduisition } \\
\text { additional }\end{array}$ & $227960 €$ & $342538 €$ & $273417 €$ \\
\hline $\begin{array}{r}\text { FPRNM } \\
\text { charges included) }\end{array}$ & & & \\
\hline
\end{tabular}

Table 1: Assessment of amicable acquisitions of properties threatened by coastal flooding as a result of the Xynthia storm (as of 31/12/2015)

\subsection{Requalification of affected territories}

Beyond these immediate measures of National Solidarity, the victim territories requalification studies were conducted to requalify the damaged territories, specifically in the municipalities of La Faute sur Mer and L'Aiguillon sur Mer in Vendee in order to redevelop and maintain activities on them which are compatible with the risk of flooding. In Charente-Maritime requalification studies on a larger territory were the subject of a national workshop.

Moreover the State services, in consultation with communities, pursue the development of priority coastal risk prevention plans identified in 2011 by the ministerial circular of 2 August 2011 [6] to ensure the control of urbanization and to restrict exposure to risk (30 municipalities are involved in the Pays de Loire, PoitouCharentes 81).

\section{Conclusion}

The 2010 Xynthia storm and Var floods unfortunately left a terrible assessment pushing to continue and accelerate the implementation of the national flood prevention policy. Many actions of the national plan for rapid submersions (PSR) helped anticipating and supporting the national flood risk management strategy 
(SNGRI), approved by the Minister of Environment, October 7, 2014 [7].

This new dynamic has allowed local authorities to mobilize on the whole territory.. They have the ability to build global prevention projects adapted to their territory and of improved quality.

\section{References}

[1] Anziani, A. (2010) RAPPORT D'INFORMATION

FAIT au nom de la mission commune d'information sur les conséquences de la tempête Xynthia (rapport d'étape) No 554, SÉNAT, SESSION ORDINAIRE DE 2009-2010 Enregistré à la Présidence du Sénat le 10 juin 2010

[2] Plan submersions rapides (2011) Submersions marines, crues soudaines et ruptures de digues; Plan interministériel coordonné par le Ministère de l'Écologie, du Développement durable, des Transports et du Logement, 78p. http://catalogue.prim.net/164 plansubmersions-rapides-submersions-marines-cruessoudaines-et-ruptures-de-digues.html

[3] DIRECTIVE 2007/60/CE DU PARLEMENT EUROPÉEN ET DU CONSEIL du 23 octobre 2007 relative à l'évaluation et à la gestion des risques d'inondation http://eur-lex.europa.eu/legalcontent/FR/TXT/PDF/?uri=CELEX:32007L0060\&qid=1 $\underline{467320318452 \& \text { from }=\mathrm{EN}}$

[4] Ministère de l'Ecologie, du Développement durable et de l'Energie (2014) Guide méthodologique : Plan de prévention des risques littoraux. Direction Générale de la Prévention des Risques, Service des Risques Naturels et Hydrauliques, $168 \mathrm{p}$.

http://catalogue.prim.net/238 guide-methodologiqueplan-de-prevention-des-risques-littoraux.html

[5] LOI n ${ }^{\circ} 2014-58$ du 27 janvier 2014 de modernisation de l'action publique territoriale et d'affirmation des métropoles

https://www.legifrance.gouv.fr/affichTexte.do?cidTexte= JORFTEXT000028526298

[6] Circulaire du 2 août 2011 relative à la mise en oeuvre des plans de prévention des risques naturels littoraux http://circulaire.legifrance.gouv.fr/pdf/2011/08/cir 33615 .pdf

[7] DGPR (2014) Stratégie Nationale de Gestion des Risques Inondation. Ministère de l'Ecologie, du Développement Durable et de l'Energie, 24p. 